\title{
The Role of Creative Thinking in the Process of Forming Teachers' Professional Identity
}

\author{
Adva Margaliot ${ }^{1}$, Naomi Magid ${ }^{2}$ \\ ${ }^{1}$ Department of Science Teachers' Education, Hakibbuzim College of Education, Technology and the Arts, Tel Aviv, Israel \\ ${ }^{2}$ Talpiot Academic College, Holon, Israel \\ Email: adva.margaliot@smkb.ac.il,nmagid@gmail.com
}

How to cite this paper: Margaliot, A., \& Magid, N. (2020). The Role of Creative Thinking in the Process of Forming Teachers' Professional Identity. Creative Education, 11, 1026-1041.

https://doi.org/10.4236/ce.2020.117074

Received: June 8, 2020

Accepted: July 13, 2020

Published: July 16, 2020

Copyright $\odot 2020$ by author(s) and Scientific Research Publishing Inc. This work is licensed under the Creative Commons Attribution International License (CC BY 4.0).

http://creativecommons.org/licenses/by/4.0/

(c) (i) Open Access

\begin{abstract}
This study tracks the influence of creative thinking on the emerging professional identity of excellent student teachers. It is based on the responses of 120 participants in an accelerated academic program towards a B.Ed. and teacher's certificate. The trainees are an inter-collegiate group from across Israel, with a range of demographic, religious, and ethnic backgrounds. They were part of the "Creativity that Changes Learning" program, which combines the theoretical subject matter of creativity with activities designed to make learning a more interactive and dynamic experience, actively engaging students in generating knowledge. Participants evaluated their learning experience. They noted that creative instruction requires extra effort. They viewed the learning environment as supporting the subject matter. They identified that teamwork contributes to the variety and diversity of ideas. They noted the multicultural nature of the group helped them understand the challenges they are likely to encounter as teachers. Findings show that the element of creative thinking was added as a part of their emerging professional identities. They expressed hesitation about the possibility of implementing creative instruction while being trained by veteran teachers who, in their estimation, would be reluctant to allow deviation from the standard lesson format.
\end{abstract}

\section{Keywords}

Teachers' Training, Creativity, Teachers' Personal, Professional Identity

\section{Introduction}

Creative thinking pertains to a person, a process and a creative product (Kaufman \& Beghetto, 2009). It involves the confluence of motivation, personal character traits and emotions (Cropley, 1999), problem-solving abilities (Barak \& Albert, 2017), use of imagination (Dziedziewicz \& Karwowski, 2015) and perseverance 
when dealing with uncertainty (Plucker, Beghetto, \& Dow, 2004). Yamin (2017) defines creativity as the ability to execute a task in a unique, original and relevant manner, taking into account the limitations of the task or the situation. Plucker and Dow (2010) include the importance of the interaction between different perspectives, and the processes and environment in which an individual or group produces an original, useful product in a social setting. Creative thinking is identified as a stimulus for social growth in culture and industry, given that original and innovative thinking, problem-solving and coping with uncertainty are required in every field (Yamin, 2017).

The last era exposed the role of creative thinking as an essential component of teachers' work. Under the Corona crisis, while students located away from their home schools, teachers' ability to harness their creativity and cause their students to be engaged in the learning process via ICT, becomes to be a matter of survival. This study examines whether the method of teaching creative thinking as it is applied here, encourages participant's motivation to be more creative as teachers in the future, and therefore it may be worth for sharing with the community of professionals.

\subsection{Creative Thinking in Teaching and Learning}

Lubart and Batton (2017) maintain that a lesson that encourages creativity must include both divergent and convergent thinking. The creative process includes detecting the problem, identifying the limitations of actions, being flexible, adapting, raising different ideas, comparing sources of information and exploring contradictory ideas. Grohman \& Szmidt (2013) and Plucker \& Dow (2010) argue that creative thinking can enhance teacher instruction and student learning and is therefore an important part of teacher training that can influence the professional identity of future teachers.

Creative teaching must encourage playfulness, imagination, flexibility, openness and dynamism, and cultivate curiosity, investigation, and various mechanisms for developing new ideas (Craft, 2011; Grohman \& Szmidt, 2013). Cheung and Leung (2013) maintain that teachers must create an atmosphere that encourages student collaboration and active involvement in learning. The creative teacher must encourage students to be self-directed and flexible thinkers, create varied opportunities for learning content, and use an assortment of tools, structures and concepts that will enable students to express themselves in a variety of ways (Craft, 2011).

Lin (2011) presents a model that includes creative teaching - teaching towards the development of creativity and creative learning. According to Lin, creative pedagogy is an educational practice that supports the development of creative ideas and outcomes. Craft (2005) describes the complementary nature of creative instruction, on the one hand, and instruction for creative development, on the other. The first focuses on actions that the teacher takes, while the second focuses on activities by the students, and encourages students to be active. 
Studies show that learning in a multicultural environment helps develop fertile thinking, flexibility and creativity; exposes participants to different perceptions and ideas; and influences their ability to use ideas from different cultures and to retrieve unusual information and raise far-flung associations in order to come up with fruitful ideas (Chang et al., 2014; Dziedziewicz, Gadja, \& Karwowski, 2014; Leung, Maddux, Galinsky, \& Chiu, 2008).

According to Selkrig and Keamy (2017), "Teachers need to be informed not only about how to teach creatively and for creativity, but also how to consider possibilities and understanding things in new ways, thereby making a case that a teacher's own creative learning is crucial" (p. 317). It was in this spirit that the "Creativity that Changes Learning" program was created for Israel's national excellence program for teaching trainees. The goal of the program is to expose participants to the untapped potential of creativity and its implementation in the classroom.

According to education researchers, excellent teachers are creative teachers-creative people who are able to foster creativity in their students (Das, Dewhurst, \& Gray, 2011; Gregerson, Kaufman, \& Snyder, 2013). Thus, the importance of creative thinking among future teachers is evident. The question remains how this skill should be developed such that it influences a teacher's emerging professional identity.

\subsection{Teachers' Professional Identity}

Professional identity is difficult to define. It includes a person's perception of his own self-worth, as well as a sense of belonging to the profession and what it represents. Teachers' professional identity includes the way a teacher perceives himself, and the way his colleagues, students and the parent-body perceive him. Creative thinking is not usually a component of this definition.

Lamote and Engles (2010) maintain that teachers' sense of professional identities is connected to their manner of teaching and their perceived possibilities for action. Their professional development is informed by their idea of what type of teacher they seek to be. Professional identity can be defined from an internal point of view, arising from the question, "How do I see myself?" It can also be defined from the external point of view, arising from the question, "How do others perceive me?" (Dugas, 2016). Identity can be understood as a narrative-an internal story about the past, present and future that one desires in order to have a meaningful life experience.

The concept of "social identity" is relevant in teacher-training. Teachers-intraining experience many different things during their training, and a conception of their ideal professional identity takes shape. This identity includes both their current perception of themselves and their perception of what type of teacher they wish to be in the future. Individual life experience, learning environments, knowledge base and teaching experiences, among other factors, influence professional identity (Lamote \& Engles, 2010). 


\section{Course Description}

The course was designed to expose students to theories of creative thinking through non-conventional means. This approach aims to demonstrate the potential of intertwining theory and practices for improving the learning experience.

The theories chosen for the course were: Advanced Systematic Inventive Thinking (ASIT), melioration, and the theory of meaning. These theories were chosen for two reasons: Firstly, because of the differences between them, and secondly, because they have the potential to be incorporated into subject matter covered in the school system's core curriculum. The selected topics demonstrated the wealth of different approaches to study and learning creative thinking, while emphasis and focal points of each approach, for a knowledge base in the field of inviting and encouraging to deepen the topic.

ASIT is often used to address mathematics and the natural sciences. It deals with problem-solving and development of new products. It is based upon the Closed World condition and the Qualitative Change condition. Implementing the Closed World condition means using it only with the existing components of the problem. The Qualitative Change condition means the identification of the factor that causes the problem and harnessing it to arrive at a solution. ASIT also uses: Multiplication or Division, Breaking Symmetry, Unification, and Waiver of Component, as actions that can be used with the problem's components (Barak \& Albert, 2017; Turner, 2009).

The skill of melioration is defined as: "The ability to identify an appropriate combination of information and apply it to problem-solving, thereby improving the aggregate" (Passig, 2003: p. 85). This method encourages the development of novel ideas by connecting content from distant disciplines. The process goes through a five-stage spiral model that includes intent, process, product, assessment and continuity (Margaliot, 2012). This model gradually integrates personal knowledge with cultural awareness and scientific data to bring about improvement in a specific domain.

The theory of meaning (Kreitler \& Kreitler, 1990) provides a framework for communicating or explaining a word, text or idea that can be expressed verbally, visually, through movement, etc. The dimensions of meaning include four classifications of content: dimensions of relevance and context; dimensions of the internal world; physical dimensions; and dynamic dimensions (Margaliot, 2012). Each category of dimensions includes a set of questions that are intended to answer the question "What is being discussed?" The questions facilitate open communication and help people ask questions about the content under discussion.

Figure 1, outlines the construct of learning sessions, developed for the course. Guided by this format, each session involved a combination of both theory \& practice, in a way that the study of theory combined with activities including games, movies and non-sensical content. Participants came to understand the connection between the theories and the activities through experiential, active play with the materials; they continued to develop their ideas and activities through the course's website. 

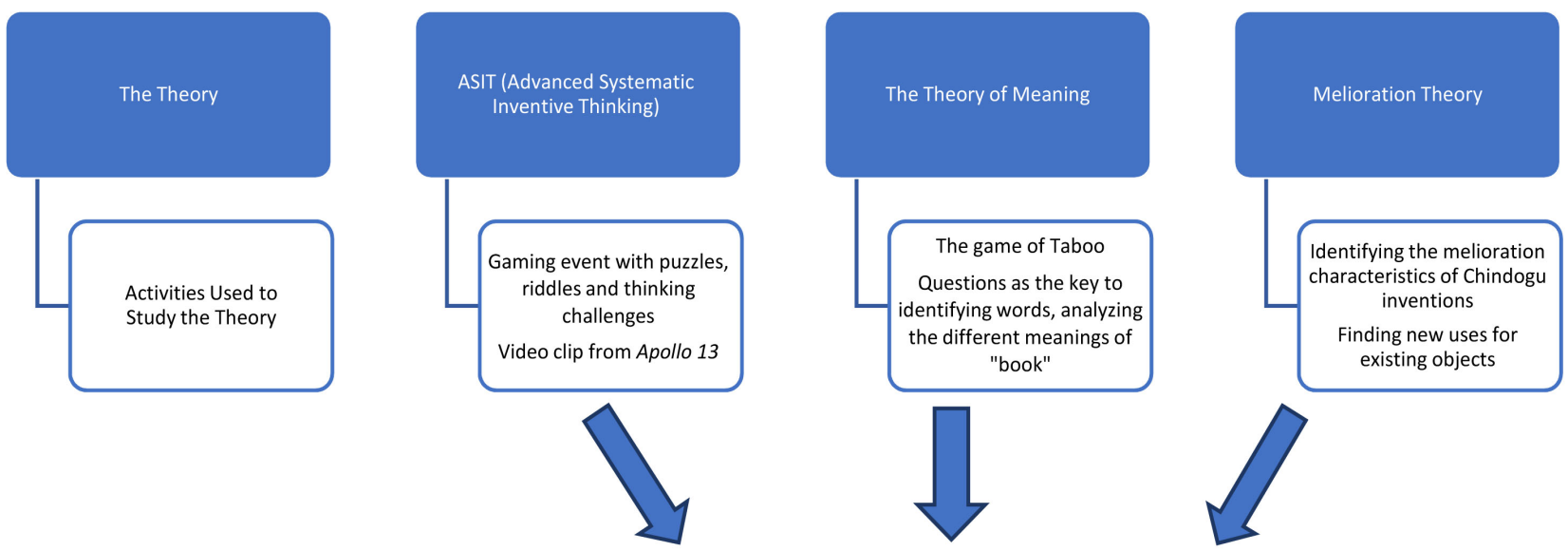

Activities that demand active participation to apply the theories of creative learning

Figure 1. The model of the learning process that connects theory and practice.

\subsection{Description of the Sessions}

The ASIT session was conducted as a fast-paced "gaming event" featuring math challenges, riddles, and various puzzles. The theory was presented afterwards, and participants mapped and matched each of the riddles to one of the thinking tools (Multiplication, Division, Breaking Symmetry, etc.). Then a clip was shown from the movie Apollo 13 (a well-known clip from Appolo 13 was shown). The movie clip provided an example of the Closed World condition. The session included children's books in which everyday problems were solved using creative solutions. The session ended with a discussion about applying these principles in school settings.

The session on the melioration model was taught through Chindogu's inventions (http://www.chindogu.com). Chindogu aims to provide intentionally nonimplementable solutions for everyday problems. Participants practiced problem-solving while their thinking is free from the need to produce a pragmatic solution. The purpose was to escape the limitations of producing products which requires that one find "the right solution". Participants were then challenged to invoke the principles of melioration to find new uses for existing objects, such as a CD holder.

The theory of meaning was applied by playing a word identification game, based on the structure of the game "Taboo." Participants used the questions of the theory of meaning to guess a hidden word. Another activity also focused on different meanings of the concept of a "book" through two children's books: We Are in a Book by Mo Willems (2016) and It's a Book by Lane Smith (2011). 
Through experiential learning activities, participants actively discovered theoretical principles and applied each theory's thinking precepts. They problem-solved, established models, and conducted discussions. The advanced abilities of these participants allowed for quick, dynamic transitions between the theories and application. The participants presented the activities that they developed on the course's website, sparking responses and discussions that further developed and refined the initial ideas.

\subsection{Participants and Setting}

REGEV (Hebrew acronym for "self-starter in education") is an honours track in teacher education. A total of 1350 teachers-in-training participate in this accelerated three-year undergraduate program towards a B. Ed. that includes a teacher's certificate. Out of all the students, about 120 of them, coming from all the teacher education colleges in Israel and from all social sectors-religious and secular Jews, Christians, and Muslims - come to study in a unique program known as the inter-collegial students' forum. Recognised for academic credits, the program spans one academic year and involves six full day seminars. Each student can choose one of four interest groups: Computer-Based Learning Games; A Visual Journey; Dialogue on Social Dilemmas; and Creativity that Changes Learning. It is the work of this last group that is discussed in the present study.

The group was composed of outstanding, highly-motivated students, specializing in different fields of education. They come from different backgrounds and ethnicities. There were male and female participants, ranging in age from 20 to 45 years old.

Over the course of three years, from 2013 until 2016, groups of 44, 37 and 39 students, respectively, participated in this course. This included 96 women and 24 men, as teaching profession yet considered to be generally more feminine option. Participants came from 22 different teacher-training programs throughout Israel.

\section{Methodology}

\subsection{Research Question}

How do participants describe their learning experience in the "Creativity that Changes Learning" program and its impact on them as future teachers?

\subsection{Data Collection Method}

Upon completing the course, participants were asked to fill out a questionnaire that included both open-ended and closed-ended questions dealing with different aspects of the course. These responses were analysed for the purpose of assessing the learning in the course. For example, the questionnaires asked: How would you describe your learning experience and its contribution to your future teaching? What aspects of the process that you underwent are important for you to share with your colleagues in the course and in your teacher-training college? 
Ethics approval was sought and granted from the directorate of the program in the ministry of education. The respondents' anonymity was guaranteed. Questionnaire responses were analysed only after participants had received course accreditation and had explicitly gave written agreed to participate in the study.

\subsection{Data Analysis}

Data was collected from three successive cohorts who participated in a program with a similar format. The qualitative findings were analysed according to categorical content analysis (Elo \& Kyngas, 2008). In total, 140 statements were analysed. A statement was defined as a sentence or a number of sentences that related to the learning experience and its contribution to the respondent, or the respondent's perspective on how the program contributed to the development of his professional identity. The categories were identified independently by each researcher to establish the validity of the statements. Afterwards, they discussed the areas in which they disagreed and reached a consensus within each category (Seidel \& Kelle, 1995). Qualitative analysis of open-ended questions enabled us to employ a bottom-up process (Maykut \& Morehouse, 1994; Saldana, 2015) to derive respondents' attitudes about the way they perceived learning in the course in response to our research question, and the attitudes that they developed towards creativity in teaching. Inter-rater reliability was $85 \%$.

\section{Research Findings}

The research question sought to examine how participants describe their learning experience in the "Creativity that Changes Learning" program and their attitudes towards it after participating in the program. For the purpose of analysing respondents' answers, only those statements that directly related to the course and its implications were used. We found 140 statements such statements. They were sorted into three categories: acquisition of knowledge, understanding and practical application; the learning experience; and adopting creative thinking as a component in establishing professional identity.

The following is a description of the three categories, accompanied by relevant statements:

\subsection{Acquisition of Knowledge, Understanding and Practical Application of Creative Thinking (Table 1)}

In relating to the course of study, participants noted that they acquired understanding of and academic knowledge about creativity, in general, and about creativity in teaching in particular. They also noted that they acquired practical pedagogical information that will be useful to them in implementing creativity in the classroom in the future. Many responses (54) included a reference to the knowledge, understanding and practical application that they gained in general, or focused on specific topics that they defined as significant to them. Several representative statements have been selected from among these responses. 
Table 1. Statements that relate to the acquisition of knowledge, understanding and practical application of creative thinking.

\begin{tabular}{|c|c|c|c|c|}
\hline \multicolumn{3}{|c|}{$\begin{array}{l}\text { Statement } \\
\text { number/teacher-training } \\
\text { college/cohort }\end{array}$} & \multirow[b]{2}{*}{$\begin{array}{l}\text { "I always thought that in order to be creative, one needs to incorporate } \\
\text { things that are not related to the topic or the learning, but in the } \\
\text { program, we learned that one of the methods of creativity is } \\
\text { to use the "data" in the problem itself." }\end{array}$} & Significance \\
\hline 1 & 1 & 2 & & $\begin{array}{l}\text { The participant understood that } \\
\text { creativity is promoted by focusing } \\
\text { on the problem itself. }\end{array}$ \\
\hline 2 & 5 & 3 & $\begin{array}{l}\text { "A place where you open your mind to new avenues that do not exist in } \\
\text { college constitutes, for me, a different level of thinking; not thinking } \\
\text { along the lines of completing assignments and tests, but rather thinking } \\
\text { deeply about goals, in and through coping in different situations." }\end{array}$ & $\begin{array}{l}\text { The speaker relates to thinking } \\
\text { deeply about goals, which is } \\
\text { different than thinking that relates } \\
\text { to formal academic assignments. }\end{array}$ \\
\hline 3 & 11 & 3 & $\begin{array}{l}\text { "I felt that I gained a lot of information and was enriched in content } \\
\text { and new materials. After each session, I really felt that I was lucky to be } \\
\text { on this path! I learned a lot and I have already been able } \\
\text { to apply things and I am certain that I will use it again." }\end{array}$ & $\begin{array}{l}\text { The participant acquired } \\
\text { information, has begun to apply } \\
\text { it and will use it in the future. }\end{array}$ \\
\hline 4 & 16 & 1 & $\begin{array}{l}\text { "We were exposed to ideas for sparking creativity through pictures, } \\
\text { impossible combinations, and a sudden change in our physical location." }\end{array}$ & $\begin{array}{l}\text { The participant points to the } \\
\text { need to make unexpected } \\
\text { connections and sudden changes. }\end{array}$ \\
\hline 5 & 19 & 2 & $\begin{array}{l}\text { "The course taught us that there is no such thing as an individual who } \\
\text { cannot be creative, and that we can be creative with everything } \\
\text { that surrounds us, not only in the realm of formal study." }\end{array}$ & $\begin{array}{l}\text { This statement demonstrates } \\
\text { that creativity can be achieved } \\
\text { in every discipline. }\end{array}$ \\
\hline 6 & 2 & 1 & $\begin{array}{l}\text { "The process that we underwent opens us to a journey that hopefully } \\
\text { won't end when the course ends but will continue to develop as we } \\
\text { cultivate our own creative thinking and creative thinking in our students." }\end{array}$ & $\begin{array}{l}\text { It is apparent that this is an } \\
\text { ongoing process that } \\
\text { should be continued. }\end{array}$ \\
\hline
\end{tabular}

Respondents related to both the course content and the learning style. They noted that they gained knowledge in subject matter that was previously unfamiliar to them and that had not been addressed in their teacher-training colleges. They affirmed that this knowledge opened new horizons for them and they were able to identify and name what was novel for them in the course. One participant noted that using the information contained in the problem itself was a novel concept to him. Another noted that she was exposed to impossible combinations demonstrated in pictures. After they described what was new to them, they noted that creative thinking is possible for them. Furthermore, they said that the learning contributed to thinking thoroughly about goals and coping in different situations. The respondents established a connection between the program's contributions to thinking and their attitudes towards the learning process. They indicated that they were exposed to ideas that unleashed their creativity (maintaining that creativity should be sparked in order to be generated) and said that they felt lucky to have taken part in this program. They related to the content studied and expressed a sense of capability about using their acquired knowledge and thinking skills in the future.

\subsection{The Learning Experience (Table 2)}

Participants described feeling free from pressures in the course. They spoke about happiness, curiosity and comfort (statement 2 ). The learning environment was 
described as warm, open and tolerant, and was perceived as a greater promoter of creativity than the innovative ideas themselves (statement 4).

In their words, the academic-pedagogical component was intrinsically connected to the emotional component, and the connection between them was what differentiated the learning in this course from previous learning environments (statement 1). Participants assessed their creative abilities-the ways in which they could act to be creative themselves and develop creativity in their students. The statements demonstrate that they experienced a shift in consciousness and that they feel able to take risks, make mistakes and relinquish control (statement 3). Responses include expressions of self-efficacy. Participants explained that creativity is a "matter of choice", meaning every person can be creative in his own way and in his environment. They express an understanding that creativity is their responsibility and that it is does not depend on someone or something else making a change (statement 5). They noted that the process is a deep one, generating a wealth of ideas (statement 7). Respondents understood that one needs to be bold and to forgo assured success. They also understood that processes require time and patience.

Table 2. Statements that relate to the learning experience in the "Creativity that Changes Learning" program.

\begin{tabular}{|c|c|c|c|c|}
\hline \multicolumn{3}{|c|}{$\begin{array}{l}\text { Statement number/Teacher } \\
\text { training college/cohort }\end{array}$} & Sample excerpt-out of 40 statements & Significance \\
\hline 1 & 12 & 3 & $\begin{array}{l}\text { "[It is] a nurturing environment that allows for creativity and } \\
\text { broadens horizons without any pressure, so different than } \\
\text { any other learning experience I have encountered." }\end{array}$ & $\begin{array}{l}\text { Notes the absence of academic } \\
\text { pressure }\end{array}$ \\
\hline 2 & 3 & 1 & $\begin{array}{l}\text { "I felt that I received a lot here, that I was happy to come each time, } \\
\text { curious and ready to learn." }\end{array}$ & $\begin{array}{l}\text { Notes curiosity, } \\
\text { happiness and openness }\end{array}$ \\
\hline 3 & 7 & 2 & $\begin{array}{l}\text { "I felt that the course warmed my heart, the atmosphere was pleasant, } \\
\text { warm and fun, which is a great opening into learning subject matter } \\
\text { from this channel; it opened the mind and the heart." }\end{array}$ & $\begin{array}{l}\text { Points to the pleasant atmosphere } \\
\text { as the basis for conceptual and } \\
\text { emotional openness. }\end{array}$ \\
\hline 4 & 14 & 2 & $\begin{array}{l}\text { "I gained an appreciation for humanity and an openness to diversity, } \\
\text { which indirectly contributed to my positive feelings, even more than } \\
\text { the creativity and new ideas that were presented by the program, } \\
\text { though I will use those, as well." }\end{array}$ & $\begin{array}{l}\text { Notes human openness and tolerance } \\
\text { as an encouraging and supportive } \\
\text { source for generating new ideas. }\end{array}$ \\
\hline 5 & 18 & 3 & $\begin{array}{l}\text { "I learned to take chances and to think differently, to let creativity } \\
\text { lead me and not to always lead it. I learned that I can be a trailblazer, } \\
\text { to lead, think, learn from mistakes, believe in my abilities, } \\
\text { and understand that the process takes time and patience. And even } \\
\text { further, that creativity is within me, I just need to find it. } \\
\text { "It's not distant... it's not across the sea..." }\end{array}$ & $\begin{array}{l}\text { There is a willingness to take chances, } \\
\text { and participate in a process whose } \\
\text { end is unknown. Uncovering the } \\
\text { capacity to promote creativity } \\
\text { brings about pleasure. }\end{array}$ \\
\hline 6 & 13 & 2 & $\begin{array}{l}\text { "We were exposed to an entire world, filled with a variety } \\
\text { of colours, ideas, different ways of thinking and such } \\
\text { diverse methods of instruction." }\end{array}$ & $\begin{array}{l}\text { Notes the wealth of ideas, including } \\
\text { the feelings, methods of teaching, } \\
\text { and ideas. }\end{array}$ \\
\hline 7 & 9 & 3 & $\begin{array}{l}\text { "The experience is actually not only fun and refreshing during the } \\
\text { sessions; it's really a process of understanding that stays in the } \\
\text { deepest layers of memory and will be used as I continue on my path, } \\
\text { thanks to a wide range of experiential methods-games, discussion, } \\
\text { thinking and writing-to sum it up." }\end{array}$ & $\begin{array}{l}\text { The respondent notes the connection } \\
\text { between experiential learning and } \\
\text { deep understanding. }\end{array}$ \\
\hline
\end{tabular}




\subsection{Adopting Creative Thinking as a Component of the Emerging Professional Identity (Table 3)}

The responses indicate that participants adopted creative thinking as a component of their professional identity (statements 3 - 6). They describe the kind of teachers they seek to become in light of their experience in the course and the style of activities they were exposed to. They related to multicultural engagement and cooperative work as driving forces in teaching (statements 1,2 ). They related

Table 3. Statements that describe creative thinking as a component in the emerging professional identity.

\begin{tabular}{|c|c|c|c|c|}
\hline \multicolumn{3}{|c|}{$\begin{array}{l}\text { Statement number/Teacher-training } \\
\text { college/cohort }\end{array}$} & \multirow{2}{*}{$\begin{array}{l}\text { Sample excerpt-out of } 46 \text { statements } \\
\text { "I recommend that any student who comes to the inter-collegiate } \\
\text { courses open up to and become familiar with the possibility of } \\
\text { integration-integrating the course work with his own personal } \\
\text { credo and getting ideas from other students who are studying } \\
\text { completely different fields." }\end{array}$} & \multirow{2}{*}{$\begin{array}{l}\text { Significance } \\
\text { Recommends the integration of } \\
\text { pedagogic rationale with } \\
\text { program content and ideas of } \\
\text { other participants. }\end{array}$} \\
\hline 1 & 6 & 1 & & \\
\hline 2 & 10 & 2 & $\begin{array}{l}\text { "The concept of teamwork was also strengthened for us. We saw } \\
\text { and experienced the dramatic increase in creativity that happens } \\
\text { when we work together in a group and cultivate each other's ideas." }\end{array}$ & $\begin{array}{l}\text { Group work and its contribution } \\
\text { are sources of creativity. }\end{array}$ \\
\hline 3 & 21 & 1 & $\begin{array}{l}\text { "This experience taught me that there are many ways to teach } \\
\text { subject matter. As teachers, our goal is to teach material in an } \\
\text { interesting, different way that will challenge students and develop } \\
\text { their skills to the maximum, in the best way possible. } \\
\text { For that reason, a teacher needs to be creative and dare to teach } \\
\text { a different way, a way that he believes in." }\end{array}$ & $\begin{array}{l}\text { Teaching must be pursued in a } \\
\text { variety of ways, teachers need to } \\
\text { challenge students, and be } \\
\text { daring in their } \\
\text { professional approach. }\end{array}$ \\
\hline 4 & 17 & 2 & $\begin{array}{l}\text { "I believe that the integration of the students-ideas, thoughts, } \\
\text { materials and learning styles-can be a winning combination } \\
\text { for creating meaningful learning experiences for students } \\
\text { in modern times." }\end{array}$ & $\begin{array}{l}\text { Integration of students, } \\
\text { thoughts, materials and learning } \\
\text { styles help facilitate meaningful } \\
\text { learning. }\end{array}$ \\
\hline 5 & 9 & 3 & $\begin{array}{l}\text { "I am confident that thinking out of the box is ultimately beneficial } \\
\text { not only to students, but also to the teacher, who will end up } \\
\text { enjoying herself more. I even think it can improve the teacher's } \\
\text { confidence in her own abilities and in the tools she uses. That is } \\
\text { why we need to continually assess ourselves-is the easier choice, } \\
\text { the one that is familiar and readily available, also the right choice, } \\
\text { the one that is most enjoyable and effective in teaching the material?" }\end{array}$ & $\begin{array}{l}\text { Creativity benefits and improves } \\
\text { the professional confidence of } \\
\text { the teacher, strengthens him and } \\
\text { contributes to the teacher's } \\
\text { ability to self-assess. }\end{array}$ \\
\hline 6 & 5 & 3 & $\begin{array}{l}\text { "This course inspired me to delve deeper and deeper into education, } \\
\text { to understand and explore different educational methodologies, } \\
\text { thereby reaching a deep and real understanding of creative thinking } \\
\text { in education. My participation in the course raised a lot of dialogue } \\
\text { about the topic, which in turn helped to refine and clarify it more. } \\
\text { Without a doubt, participating in this course is a change of direction } \\
\text { for our professional development as teachers. The ability to think } \\
\text { out of the box helps us, as educators, manage to reach also students } \\
\text { who are struggling and to find the right path to success by investing } \\
\text { ourselves and approaching the subject matter differently." }\end{array}$ & $\begin{array}{l}\text { The course inspires deep inquiry } \\
\text { of creativity in education and its } \\
\text { influence on the professional } \\
\text { identity of educators and their } \\
\text { ability to help struggling } \\
\text { students achieve more. }\end{array}$ \\
\hline
\end{tabular}


to the wealth of ideas and the existence of a personal educational credo, alongside the importance and impact of creating challenges, taking chances, being daring and invoking interesting methods of teaching (statements 3,4). For them, a teacher is someone who examines, clarifies and assesses his path in order to find the best ways to address the various needs of his students (statements $4,5,6$ ).

\section{Discussion}

This study was designed to explore how outstanding teaching trainees perceive their learning experience in the "Creativity that Changes Learning" course and how they perceive the role of creative thinking in their professional capacity as future educators.

The mission we set for ourselves was to motivate the teaching trainees to create, and to be involved and interested, through tasks that offer new game-like spaces to explore. We sought to enable participants to identify their inherent potential and understand what creative thinking is, so that it could become one of their resources for developing original thinking about teaching content and learning processes. Our aim for each learning session was for it to become a unique and meaningful experience for the students so that they would be able to translate that into a personal and pedagogical viewpoint in which creativity plays a central role.

Both features of the group-its multicultural composition and the highlymotivated, high-capability nature of participants-can enhance creativity (Maddux, Adam, \& Galinsky, 2010; Klavir \& Gorodetsky, 2011). The understanding that this unique group presented an opportunity for a unique human encounter led us to plan and lead an educational adventure shared by the students and ourselves.

A highly diverse group can create opportunities to inspire group and individual creativity. Instead of viewing it as a challenge, we decided to view diversity as a valuable opportunity (Dziedziewicz, Gajda, \& Karwowski, 2014). We consciously decided to use this diversity to leverage learning and shape new personal, educational and professional outlooks. Maddux, Adam and Galinsky (2010) address the role of a multicultural group: "Multicultural experiences help [....] facilitate an appreciation that the same problem can have multiple solutions" (p. 738).

Participants' responses indicate that they identified the contribution of the multicultural nature of the group to learning in new ways, that it left a mark on them, and influenced their understanding of their job. Consistent with Lin's (2011) recommendation, the participants thought that the differences among group members was fertile ground for ideas (Table 3, statements 1, 2, 4). They saw their colleagues as a helpful resource and noted that this was a new experience that would not have been possible in their respective colleges. They further noted that they were surprised by both the quality and the depth of the multicultural encounter (Table 3, statement 6). 
The teaching methodologies presented in the course benefited participants, as demonstrated by the respondent (Table 1 , statement 1 ) who realised that he could take advantage of the Closed World condition in systematic inventive thinking. One participant saw melioration as a source for generating ideas (Table 1, statement 4). They noted behaviours that support creative thinking (Table 2, statement 5): "I learned to take risks, to think differently." This corresponds to Lubart and Batton's (2017) assertion that risk-taking is a pre-requisite to creative thinking. One respondent (Table 2, statement 7) pointed to an all-encompassing benefit: "A process of understanding that stays in the deepest layers of memory."

The respondents' answers demonstrate that the course influenced their professional identity. Kenny, Finneran and Mitchell (2015) assert that the professional identity of teachers-in-training undergoes "developmental transformation" when practical knowledge joins theoretical information and supports the feeling of self-efficacy, and they understand that they can act effectively, in a variety of ways, confident in their ability to succeed. The respondents expressed this (Table 3, statements 4,5). Respondents affirm that their experiences caused them to think deeply about their future profession. They see congruence between their exploration and their ability to provide for their students' needs (Table 3, statements 5, 6). Their understanding that the experience they gained involved exploration, examination, and contemplation, is something that stands out in their responses.

At the stage of data analysis, a component that combines the theories with the learning activities was added to the learning model. This component describes the benefit of active involvement in the building of participants' professional identity. Respondents indicated that they gained academic knowledge and pedagogical tools that they can implement in creative teaching in the future (Table 2, statement 7) (Figure 2).

The course of study was described as an experience that impacted participants' attitude towards teaching and that advanced them cognitively, emotionally, socially and professionally (Gregerson, Kaufman, \& Snyder, 2013). In the cognitive realm, they were exposed to learning materials, educational methodologies and new ways of connecting them (Table 3, statement 6). In terms of emotion, they expressed happiness and satisfaction with their choice to participate actively and they noted the benefit of an open, tolerant, pleasant environment to improved thinking skills (Table 2). On a social level, they pointed to the social interaction and its role in promoting creativity (Table 3 , statements 1,2 ).

Some participants had previously thought that creative thinking was a fixed quality. As a result of the course, they recognised that personal responsibility is necessary in order to develop creativity, both personally and pedagogically. Their responses (Table 3, statements 5,6 ) reflect the perception that was developed in accordance with the rationale of researchers, according to which teachers with positive attitudes remain inquisitive and develop teaching methodologies over time (e.g. Craft, 2005; Cheung \& Leung, 2013; Das, Dewhurst, \& Gray, 2011; Grohman \& Szmidt, 2013; Maker, Jo, \& Muammar, 2008). 

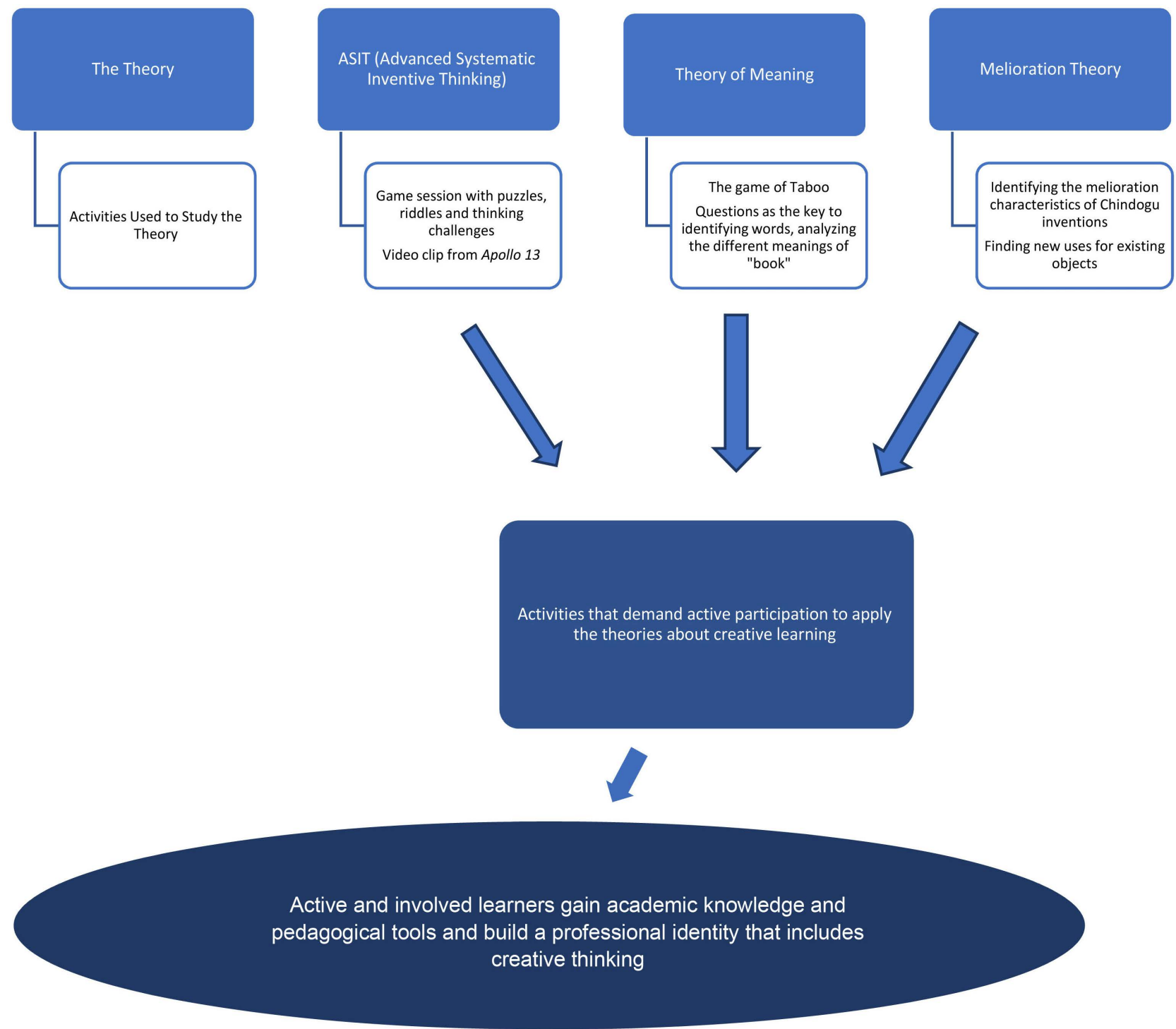

Figure 2. Present the process of the development of professional identity.

Participants expressed that the course linked learning, thinking and experience by building non-trivial connections between content, ideas and people. This affected their ability to understand the ongoing nature of the development at hand: "I think that creativity is like a ramp that leads me higher so that I can have a broader view of teaching and see new possibilities for ways to teach" (college no. 14, cohort 2).

This study assessed the perceptions that participants developed about creative thinking and its place in their emerging professional identity as future teachers. From the data, it appears that the teaching model and pedagogical methods employed were new to participants and caused them to consider how they might incorporate this style of activities as teachers in the future. The study did not assess the program's impact on students' creative thinking. We plan to dedicate another study to that fundamental topic. 


\section{Summary}

Why creativity? Our goal was to challenge excellent student-teachers to become excellent teachers. We chose to focus on developing creativity because creative thinking has been identified as one of the key thinking skills mentioned in the "Learning for the $21^{\text {st }}$ Century" report (P21 Partnership for 21st Century Learning, 2002). The curriculum designed to provide students with tools for creative learning and teaching. The participants were proactive in unearthing the principles of each theory and applying relevant thinking skills through hands-on activities. In the end-of-course feedback, students reported that they understood that they should strive to recognize opportunities to promote experiential learning so that in the future their pupils will be proactively involved in the learning process. Most of them said they felt they could rely on themselves and on their ability to think and act independently, and noted that this group experience had dispelled any fears they might have had about taking initiatives. They further mentioned that they understood that moving out of their comfort zone meant moving away from the familiar (which they find comfortable). They noted that the group activities encouraged them to be "different" as teachers, no longer satisfied with the standard ways of teaching. They claimed they had been exposed to a variety of examples and possibilities that go beyond the boundaries of the learning routinely found in schools. Finally, creativity was mentioned repeatedly in their feedback and they connected it to challenging thinking, the joy of learning and the motivation to teach and to learn. These voices leave the impression that the way to enrich student-teachers with new perceptions towards their professional role as a creative and innovative teacher, lays on the way they experience, the way they gathered their knowledge. When it is alive fulfil and creative and innovative-it might open up new perspectives for the future of their identity as an innovative \& creative teacher who may invent new scenarios for their future students.

\section{Conflicts of Interest}

The authors declare no conflicts of interest regarding the publication of this paper.

\section{References}

Barak, M., \& Albert, D. (2017). Fostering Systematic Inventive Thinking (SIT) and Self-Regulated Learning (SRL) in Problem-Solving and Troubleshooting Processes among Engineering Experts in Industry. Australasian Journal of Technology Education, 4, 1-14. https://doi.org/10.15663/ajte.v4i1.45

Chang, J. H., Hsu, C.-C, Shih, N.-H., \& Chen, H. C. (2014). Multicultural Families and Creative Children. Journal of Cross-Cultural Psychology, 45, 1288-1296. https://doi.org/10.1177/0022022114537556

Cheung, H. P. R., \& Leung, C. H. (2013). Preschool Teachers' Beliefs of Creative Pedagogy: Important for Fostering Creativity. Creativity Research Journal, 25, 397-407. https://doi.org/10.1080/10400419.2013.843334 
Craft, A. (2005). Creativity in Schools: Tensions and Dilemmas. New York: Routledge. https://doi.org/10.4324/9780203357965

Craft, A. (2011). Creativity and Education Futures: Learning in a Digital Age. Sterling: Trentham Books.

Cropley, A. (1999). Definitions of Creativity. In M. A. Runco, \& S. Pritsker (Eds.), Encyclopedia of Creativity (pp. 511-524). San Diego, CA: Academic Press.

Das, S., Dewhurst, Y., \& Gray, D. (2011). A Teacher's Repertoire: Developing Creativepedagogy. International Journal of Education and the Arts, 12, 1-40.

http://www.ijea.org/v12n15/v12n15.pdf

Dugas, D. (2016). The Ineffectiveness of "Effective" Management Strategies: First-Year Teachers, Behavior Management, and Identity. Action in Teacher Education, 38, 18-33. https://doi.org/10.1080/01626620.2015.1078754

Dziedziewicz, D., \& Karwowski, M. (2015). Development of Children's Creative Visual Imagination: A Theoretical Model and Enhancement Programmes. Education 3-13, 43, 382-392. https://doi.org/10.1080/03004279.2015.1020646

Dziedziewicz, D., Gajda, A., \& Karwowski, M. (2014). Developing Children's Intercultural Competence and Creativity. Thinking Skills and Creativity, 13, 32-42. https://doi.org/10.1016/j.tsc.2014.02.006

Elo, S., \& Kyngas, H. (2008). The Qualitative Content Analysis Process. Journal of Advanced Nursing, 62, 107-115. https://doi.org/10.1111/j.1365-2648.2007.04569.x

Gregerson, M., Kaufman, J. C., \& Snyder, H. (2013). Teaching Creatively and Teaching Creativity. New York: Springer. https://doi.org/10.1007/978-1-4614-5185-3

Grohman, M. G., \& Szmidt, K. J. (2013). Teaching for Creativity: How to Shape Creative Attitudes in Teachers and in Students. In M. Gregerson, J. Kaufman, \& H. Snyder (Eds.), Teaching Creatively and Teaching Creativity (pp. 15-35). New York: Springer. https://doi.org/10.1007/978-1-4614-5185-3_2

Kaufman, J. C., \& Beghetto, R. A. (2009). Beyond Big and Little: The Four C Model of Creativity. Review of General Psychology, 13, 1-12. https://doi.org/10.1037/a0013688

Kenny, A., Finneran, M., \& Mitchell, E. (2015). Becoming an Educator in and through the Arts: Forming and Informing Emerging Teachers' Professional Identity. Teaching and Teacher Education, 45, 159-167. https://doi.org/10.1016/j.tate.2015.03.004

Klavir, R., \& Gorodetsky, M. (2011). Features of Creativity as Expressed in the Construction of New Analogical Problems by Intellectually Gifted Students. Creative Education, 2, 164-173. https://doi.org/10.4236/ce.2011.23023

Kreitler, S., \& Kreitler, H. (1990). The Cognitive Foundations of Personality Traits. New York: Plenum. https://doi.org/10.1007/978-1-4899-2227-4

Lamote, C., \& Engels, N. (2010). The Development of Student Teachers' Professional Identity. European Journal of Teacher Education, 33, 3-18.

https://doi.org/10.1080/02619760903457735

Leung, A. K., Maddux, W. W., Galinsky, A. D., \& Chiu, C. Y. (2008). Multicultural Experience Enhances Creativity: The When and How. American Psychology, 63, 169-181. https://doi.org/10.1037/0003-066X.63.3.169

Lin, Y. S. (2011). Fostering Creativity through Education: A Conceptual Framework of Creative Pedagogy. Creative Education, 2, 149-155.

https://doi.org/10.4236/ce.2011.23021

Lubart, T., \& Batton, D. (2017). Enhancing Creativity. In T. S. Yamin, K. W. McCluskey, T. Lubart, D. Ambrose, K. McCluskey, \& S. Linke (Eds.), Innovation Education (pp. 119-128). Sweden: ICIE the International Centre for Innovation in Education. 
Maddux, W. W., Adam, H., \& Galinsky, A. D. (2010). When in Rome ... Learn Why the Romans Do What They Do: How Multicultural Learning Experiences Facilitate Creativity. Personality and Social Psychology Bulletin, 36, 731-741. https://doi.org/10.1177/0146167210367786

Maker C. J., Jo, S., \& Muammar, O. M. (2008). Development of Creativity: The Influence of Varying Levels of Implementation of the DISCOVER Curriculum Model, a Non-Traditional Pedagogical Approach. Learning and Individual Differences, 18, 402-417. https://doi.org/10.1016/j.lindif.2008.03.003

Margaliot, A. (2012). The Logic of Thinking Creatively: A Description of a Learning Process Designed at the Expansion of Creativity in Teachers' Education. In S. Kreitler, G. Fleck, D. Eigner, \& L. Ropolyi (Eds.), Systems of Logic and the Construction of Order (pp. 131-151). Frankfurt: Peter Lang.

Maykut, P., \& Morehouse, R. (1994). Beginning Qualitative Research: A Philosophic and Practical Guide. London: Falmer Press.

P21 Partnership for 21st Century Learning (2002). Framework for 21st Century Learning. http://www.p21.org/about-us/p21-framework

Passig, D. (2003). A Taxonomy of Future Higher Thinking Skills. Informatica, 2, 79-92.

Plucker, J. A., Beghetto, R. A., \& Dow, G. (2004). Why Isn't Creativity More Important to Educational Psychologists? Potential, Pitfalls, and Future Directions in Creativity Research. Educational Psychologist, 39, 83-96. https://doi.org/10.1207/s15326985ep3902_1

Plucker, J., \& Dow, G. (2010). Attitude Change as the Precursor to Creativity Enhancement. In R. Beghetto, \& J. Kaufman (Eds.), Nurturing Creativity in the Classroom (pp. 362-379). Cambridge: Cambridge University Press. https://doi.org/10.1017/CBO9780511781629.018

Saldana, J. (2015). The Coding Manual for Qualitative Researchers. https://books.google.co.il/books

Seidel, J. V., \& Kelle, U. (1995). Different Functions of Coding in the Analysis of Textual Data. In U. Kelle, G. Prein, \& K. Bird (Eds.), Computer-Aided Qualitative Data Analysis: Theory, Methods, and Practice (pp. 52-61). London: Sage.

Selkrig, M., \& Keamy, K. R. (2017). Creative Pedagogy: A Case for Teachers' Creative Learning Being at the Centre. Teaching Education, 28, 317-322. https://doi.org/10.1080/10476210.2017.1296829

Turner, S. (2009). ASIT-A Problem-Solving Strategy for Education and Eco-Friendly Sustainable Design. International Journal of Technology Education, 19, 221-235. https://doi.org/10.1007/s10798-008-9080-6

Yamin, T. S. (2017). Excellence, Creativity and Innovation Education. In T. S. Yamin, K. W. McCluskey, T. Lubart, D. Ambrose, K. McCluskey, \& S. Linke (Eds.), Innovation Education (pp. 1-14). Sweden: ICIE the International Centre for Innovation in Education. 